\title{
Feeding weaned piglets and growing-finishing pigs with diets based on mainly home-grown organic feedstuffs
}

\author{
Kirsi Partanen, Hilkka Siljander-Rasi and Timo Alaviuhkola \\ MTT Agrifood Research Finland, Animal Production Research, Pork and Poultry Production, \\ Tervamäentie 179, FI-05840 Hyvinkä̈̈, Finland, e-mail: kirsi.partanen@mtt.fi
}

In 2000, EU regulations for organic animal production set new guidelines for organic pig feeding requiring that this be based on mainly home-grown organic feedstuffs. Doubts were however raised whether these feeding regimes can maintain good growth performance and carcass quality of pigs. Three experiments were carried out to study different organic feeding regimes in weaned piglets and fattening pigs. In Experiment 1 , we evaluated the use of peas and faba beans $\left(0,120\right.$, or $\left.240 \mathrm{~g} \mathrm{~kg}^{-1}\right)$ in diets for weaned piglets. Piglets fed pea diets performed as well as those fed the control diet, whereas the highest faba bean level resulted in reduced feed intake and growth performance. In Experiment 2, we studied the replacement ( 0 , 33 , or $67 \%$ ) of rapeseed cake with blue lupins in fattening pig diets. The dietary lupin level had a quadratic effect on the weight gain of growing pigs, the best performance being observed at the $33 \%$ replacement level. However, dietary lupin level did not influence weight gain during the finishing period and total fattening. Back fat became softer with increasing dietary lupin levels. In Experiment 3, different protein supplements were compared in organic diets from weaning to slaughter. In two-phase feeding, the best performance was observed when whey protein was used as the protein supplement, followed by soya bean cake + whey protein and rapeseed cake + fish meal. The effects of a one-phase organic feeding regime with coldpressed rapeseed cake + whey protein did not differ from those of the two-phase organic feeding regimes. Fattening pigs fed organic diets required from two to seven days longer to reach slaughter weight than those fed conventional diets. Pigs fed organic diets had fatter carcasses, but the eating quality of organic pork did not differ from that of pork from pigs fed conventional diets. Feed costs and the circulation rate of pigs, weaners in particular, were greater and carcass prices lower in the organic feeding regimes than in the conventional ones.

Key words: pigs, organic farming, legumes, protein supplements, performance, carcass quality 
Partanen, K. et al. Feeding pigs with mainly home-grown organic feedstuffs

\section{Introduction}

Organic farming has been developed to meet the demands of consumers who are concerned about environmental pollution as well as animal health and welfare in conventional livestock farming. In the European Union, the Council Regulation (EC) No. 1804/1999, supplementing Regulation (EEC) No. 2092/91 on organic production, entered into force on 19 July 1999 and applied from 24 August 2000 (EC 1999). This regulation provided a standard for organic animal production, requiring that animals be fed only organic feedstuffs that are primarily produced on the farm. For a transition period of five years, the use of conventional feedstuffs in pig feeding was allowed up to a limit of $20 \%$ of the annual and $25 \%$ of the daily feed consumption, calculated as a percentage of the dry matter. The use of solvent-extracted oil seed meals, e.g. soya bean and rapeseed meal and pure amino acids, became forbidden. These feeding regulations raised doubts among organic pig producers, many of whom felt that diets that are based on primarily home-grown feedstuffs cannot meet the amino acid requirements of pigs and cannot maintain good performance level and high carcass quality at slaughter.

In organic production in Finland, pea is the main home-grown protein source used in pig feeding, but the use of faba beans is increasing. Although faba beans are richer in crude protein than peas (ca. 30\% vs. 19-25\%), they require a longer growing period and it is therefore recommended to grow them only in the southern part of the country (Järvi et al. 2000). Both peas and faba beans have been studied extensively with fattening pigs, but little information is available on the suitability of peas and faba beans for piglet feeding. Blue lupin has also received interest as a protein feedstuff for pigs, for lupin seeds have noticeably higher protein content (ca. 30-34\%) than peas (van Barneveld 1999). The growing period of blue lupins is even longer than that of faba beans, and so far only a small number of imported varieties have been tested in Finnish growing conditions.

Although organic plant production has increased rapidly, organic pig production has devel- oped slowly. In general, there has been little information available on the impact of organic feeding regimes on the performance and carcass quality of pigs to support farmers in their decisions (Sundrum 2001). This may have contributed to the low interest of farmers in shifting from conventional to organic pig farming. Particularly information on the effect of organic feeding regimes on the performance of weaned piglets is scarce, for previous studies had focused on fattening pigs only. In fattening pigs, the exclusion of amino acid supplementations from diets based on organically produced feedstuffs has reduced growth performance of pigs and increased intramuscular fat content (Sundrum et al. 2000). However, there is a lack of information concerning the effect of organic feeding regimes on the eating quality of pork (Woese et al. 1977).

The objectives of our study were to investigate in three experiments the effects of different organic feeding regimes based on home-grown feedstuffs on the performance of weaned piglets and fattening pigs and on the eating quality of pork. Firstly, we studied the use of peas and faba beans in diets for weaned piglets, secondly, the replacement of rapeseed cake with blue lupins in diets for fattening pigs, and thirdly, we compared the use of different protein supplements in cereal-pea-based organic diets from weaning to slaughter.

\section{Material and methods}

Three performance experiments were carried out with weaned piglets and (or) growing-finishing pigs using a total of 274 pigs. The experimental procedures were evaluated and approved by the Animal Care and Use Committee of MTT Agrifood Research Finland.

\section{Experiment I}

A total of 80 weaned piglets from 10 litters were used to investigate the effect on performance of 
Vol. 15 (2006): 89-105.

including increasing amounts of peas or faba beans in weaner diets. Piglets were weaned at an average age of 38 days (s.d. 2.8), when their mean body weight was $11.8 \mathrm{~kg}$. From the age of 14 days until weaning, they had received a conventional starter diet (crude protein (CP) $186 \mathrm{~g} \mathrm{~kg}^{-1}$ ). At weaning, eight piglets from each litter were randomly allotted to four pairs, which were assigned to the following five dietary treatments: control diet and diets containing 120 or $240 \mathrm{~g} \mathrm{~kg}^{-1}$ of peas (Pisum sativum cv. Karita) or of faba beans (Vicia faba cv.
Kontu) according to an incomplete block design (Cochran and Cox 1957). Piglet pairs were housed in pens measuring $0.78 \mathrm{~m} \times 1.68 \mathrm{~m}\left(0.68 \mathrm{~m}^{2}\right.$ of solid concrete floor and $0.63 \mathrm{~m}^{2}$ of plastic slatted floor) throughout the trial, which lasted for 20 days. Peat was used as bedding material.

The compositions of the experimental diets are presented in Table 1. The control diet was based on organically produced barley (cv. Inari, CP $106 \mathrm{~g}$ $\mathrm{kg}^{-1}$ ), oats (cv. Roope, CP $90 \mathrm{~g} \mathrm{~kg}^{-1}$ ), and dehulled oats (CP $103 \mathrm{~g} \mathrm{~kg}^{-1}$ ), which were supplemented

Table 1. Ingredients and calculated composition of weaner diets containing increasing levels of peas or faba beans (Experiment 1).

\begin{tabular}{|c|c|c|c|c|c|}
\hline & \multirow[b]{2}{*}{ Control } & \multicolumn{2}{|c|}{ Peas, $\mathrm{g} \mathrm{kg}^{-1}$} & \multicolumn{2}{|c|}{ Faba beans, $\mathrm{g} \mathrm{kg}^{-1}$} \\
\hline & & 120 & 240 & 120 & 240 \\
\hline \multicolumn{6}{|l|}{ Ingredients, g per kg feed } \\
\hline Barley & 300 & 300 & 300 & 300 & 300 \\
\hline Oats & 150 & 150 & 150 & 150 & 150 \\
\hline Dehulled oats & 402 & 301 & 199 & 309 & 217 \\
\hline Peas & - & 120 & 240 & - & - \\
\hline Faba beans & - & - & - & 120 & 240 \\
\hline Whey protein concentrate & 99 & 81 & 64 & 73 & 47 \\
\hline Fish meal & 20 & 20 & 20 & 20 & 20 \\
\hline Mineral and vitamin premix ${ }^{\mathrm{a}}$ & 13 & 13 & 13 & 13 & 13 \\
\hline Limestone & 10.2 & 10.2 & 10.2 & 9.8 & 9.4 \\
\hline Monocalcium phosphate & 5.6 & 4.9 & 4.1 & 5.0 & 4.4 \\
\hline \multicolumn{6}{|l|}{ Calculated composition } \\
\hline Net energy, $\mathrm{MJ} \mathrm{kg}^{-1}$ & 9.7 & 9.5 & 9.3 & 9.4 & 9.1 \\
\hline Feed units per $\mathrm{kg}(1 \mathrm{fu}=9.3 \mathrm{MJ} \mathrm{NE})$ & 1.04 & 1.02 & 1.00 & 1.01 & 0.98 \\
\hline Crude protein, $\mathrm{g} \mathrm{kg}^{-1}$ & 179 & 176 & 174 & 183 & 187 \\
\hline \multicolumn{6}{|c|}{ Apparent ileal digestible amino acids, $\mathrm{g} \mathrm{fu}^{-1}$} \\
\hline Lysine & 9.5 & 9.5 & 9.5 & 9.5 & 9.5 \\
\hline Methionine + cystine & 6.8 & 6.2 & 5.5 & 6.0 & 5.3 \\
\hline Threonine & 7.1 & 6.7 & 6.4 & 6.1 & 5.1 \\
\hline Calcium, $\mathrm{g} \mathrm{fu}^{-1}$ & 9.0 & 9.0 & 9.0 & 9.0 & 9.0 \\
\hline Phosphorus, $\mathrm{g} \mathrm{fu}^{-1}$ & 5.4 & 5.5 & 5.5 & 5.6 & 5.8 \\
\hline Digestible phosphorus, $\mathrm{g} \mathrm{fu}^{-1}$ & 3.1 & 3.1 & 3.1 & 3.1 & 3.1 \\
\hline Organic feedstuffs, $\%$ of dry matter ${ }^{b}$ & 87 & 89 & 91 & 90 & 92 \\
\hline
\end{tabular}

aPer kilogram of feed, the premix contained Ca, 2.3 g; P, 0.8 g; Mg, 0.5 g; NaCl, 3.3 g, Fe, 103 mg; Cu, 22 mg; Zn, 91 $\mathrm{mg}$; Mn, $23 \mathrm{mg}$; Se, $0.28 \mathrm{mg}$; I, $0.28 \mathrm{mg}$; vitamin A, $5170 \mathrm{IU}$, vitamin $\mathrm{D}_{3}, 517 \mathrm{IU}$; vitamin E, $50 \mathrm{mg}$; thiamin, $2 \mathrm{mg}$; riboflavin, $5 \mathrm{mg}$; pyridoxine, $3 \mathrm{mg}$; vitamin $\mathrm{B}_{12} 20 \mu \mathrm{g}$; biotin, $0.2 \mathrm{mg}$; pantothenic acid, $14 \mathrm{mg}$; niacin, $20 \mathrm{mg}$; folic acid, $2 \mathrm{mg}$; and vitamin $\mathrm{K}, 2 \mathrm{mg}$.

${ }^{\mathrm{b}}$ Cereals, peas, and faba beans were organically produced. 
Partanen, K. et al. Feeding pigs with mainly home-grown organic feedstuffs

with conventional, mechanically extracted whey protein concentrate (CP $\left.695 \mathrm{~g} \mathrm{~kg}^{-1}\right)$ and fish meal (CP $706 \mathrm{~g} \mathrm{~kg}^{-1}$ ). The control diet was formulated to meet the nutrient requirements of weaned piglets according to Tuori et al. (1996). In the other four diets, peas (CP $187 \mathrm{~g} \mathrm{~kg}^{-1}$ ) or faba beans (CP $280 \mathrm{~g}$ $\mathrm{kg}^{-1}$ ) were included instead of dehulled oats and whey protein concentrate. These diets were formulated to be similar in the apparent ileal digestible lysine content $(9.5 \mathrm{~g}$ per feed unit, $1 \mathrm{fu}=9.3 \mathrm{MJ}$ $\mathrm{NE}$ ) compared to the control diet, whereas the contents of apparent ileal digestible methinine + cystine and threonine remained somewhat lower. Cereals and legume seeds were ground in a hammer mill with a $3.5-\mathrm{mm}$ and a 4-mm sieve, respectively, and feeds were mixed in a Gehl 170 MixAll grinder-mixer (Gehl Company, West Bend, Wisconsin, USA). Feeds were available ad libitum from gravity flow feeders, and water was supplied from drinking nipples. Piglets were weighed at birth, weaning, and 13 and 20 days after weaning. Feed disappearance from feeders was determined 13 and 20 days after weaning. Diarrhoea was monitored daily and scored as follows: $0=$ solid faeces, $1=$ soft faeces, 2 = very soft faeces, $4=$ watery faeces. The diarrhoea index was calculated as a sum of daily diarrhoea scores per pen.

\section{Experiment 2}

A total of 74 pigs with an initial body weight of 27 $\mathrm{kg}$ were used to investigate the effects of the gradual replacement $(0,33$, or $67 \%)$ of rapeseed cake with blue lupins (Lupinus angustifolius cv. Pershatsvet) in organically produced barley-pea-based diets on performance and carcass characteristics of fattening pigs and on the eating quality of pork compared to the results of a conventional barley + soya bean meal based diet. The animals were housed in solid, concrete floor pens measuring 1.0 $\mathrm{m} \times 2.5 \mathrm{~m}$, two gilts or two barrows per pen. Pens were randomly allotted to four dietary treatments: ten pens to Treatment 1 , in which pigs were fed conventional barley + soya bean meal based grower and finisher diets, and nine pens to Treatments 2 to 4 , in which pigs were fed organic grower and finisher diets with rapeseed cake and lupins. Organic diets were based on organically grown barley (cv. Kustaa, CP $108 \mathrm{~g} \mathrm{~kg}^{-1}$ ) and peas (cv. Solara, CP $221 \mathrm{~g} \mathrm{~kg}^{-1}$ ), which were supplemented with conventional toasted full-fat soybeans (in grower diets only; CP $374 \mathrm{~g} \mathrm{~kg}^{-1}$ ) and warmpressed rapeseed cake (CP $\left.419 \mathrm{~g} \mathrm{~kg}^{-1}\right)$. In grower and finisher diets, different batches of lupins were used, and they were grown organically in 1998 and 1999 and contained CP 198 and $293 \mathrm{~g} \mathrm{~kg}^{-1}$, respectively.

The compositions of the grower and finisher diets are shown in Table 2. The conventional grower and finisher diets were formulated to meet the nutrient requirements of growing and finishing pigs according to Tuori et al. (1996), and they contained 8.5 and $7.0 \mathrm{~g}$ ileal digestible lysine $\mathrm{fu}^{-1}$, respectively. Organic diets were formulated so that the percentage of conventional feedstuffs did not exceed the limits set by EU regulations for organic animal production (EC 1999). To obtain this objective, lower apparent ileal digestible amino acid contents were accepted for organic than conventional diets: 7.5 and $6 \mathrm{~g}$ apparent ileal digestible lysine $\mathrm{fu}^{-1}$, respectively. Feeds were in meal form and they were prepared as in Experiment 1. The grower phase was during the initial five weeks of the experiment, whereas the finisher phase lasted until the pigs reached a body weight of $103 \mathrm{~kg}$ and were slaughtered. Pigs were offered diets according to a restricted, age-based feeding scale (1.1-2.9 fu d $\left.{ }^{-1}\right)$. Water was added on to feed before feeding. Water was also available ad libitum from drinking nipples.

\section{Experiment 3}

A total of 120 weaned piglets from 15 litters were used to investigate the effects of organic diets with different protein supplements on the performance of pigs from weaning to slaughter, as well as on carcass quality and eating quality of pork. Piglets were weaned at an average age of 36 days (s.d. 2.5 ), when their mean body weight was $10.7 \mathrm{~kg}$. From the age of $14 \mathrm{~d}$ until weaning, they had received a standard starter diet (CP $186 \mathrm{~g} \mathrm{~kg}^{-1}$ ). At 
Vol. 15 (2006): 89-105.

Table 2. Ingredients and calculated composition of organic diets in which rapeseed cake was gradually replaced with blue lupins and of conventional grower and finisher diets (Experiment 2).

\begin{tabular}{|c|c|c|c|c|c|c|c|c|}
\hline \multirow{3}{*}{$\begin{array}{l}\text { Diet type } \\
\text { Replacement level } \\
\text { Feeding phase }\end{array}$} & \multirow{2}{*}{\multicolumn{2}{|c|}{ Conventional }} & \multicolumn{6}{|c|}{ Organic, with gradual replacement of rapeseed cake with lupins } \\
\hline & & & \multicolumn{2}{|c|}{$0 \%$} & \multicolumn{2}{|c|}{$33 \%$} & \multicolumn{2}{|c|}{$67 \%$} \\
\hline & $27-55 \mathrm{~kg}$ & $55-107 \mathrm{~kg}$ & $27-55 \mathrm{~kg}$ & $55-107 \mathrm{~kg}$ & $27-55 \mathrm{~kg}$ & $55-107 \mathrm{~kg}$ & $27-55 \mathrm{~kg}$ & $5-107 \mathrm{~kg}$ \\
\hline \multicolumn{9}{|l|}{ Ingredients, $\mathrm{g}$ per $\mathrm{kg}$ of feed } \\
\hline Barley & 778 & 825 & 570 & 676 & 509 & 623 & 450 & 570 \\
\hline Peas & - & - & 160 & 150 & 160 & 150 & 160 & 150 \\
\hline Lupins & - & - & - & - & 120 & 103 & 237 & 206 \\
\hline Rapeseed cake, warm pressed & - & - & 176 & 151 & 117 & 101 & 59 & 51 \\
\hline Toasted full-fat soya beans & - & - & 70 & - & 70 & - & 70 & - \\
\hline Soya bean meal & 195 & 149 & - & - & - & - & - & - \\
\hline Mineral and vitamin premix ${ }^{a}$ & 13 & 13 & 13 & 13 & 13 & 13 & 13 & 13 \\
\hline Limestone & 8.4 & 7.9 & 9.0 & 8.3 & 8.7 & 8.0 & 8.3 & 7.7 \\
\hline Monocalcium phosphate & 4.6 & 4.0 & 1.9 & 1.7 & 2.2 & 1.9 & 2.5 & 2.1 \\
\hline L-Lysine $\mathrm{HCl}$ & 1.5 & 1.0 & - & - & - & - & - & - \\
\hline \multicolumn{9}{|l|}{ Calculated composition } \\
\hline Net energy, $\mathrm{MJ} \mathrm{kg}^{-1}$ & 9.3 & 9.4 & 9.6 & 9.4 & 9.5 & 9.3 & 9.2 & 9.2 \\
\hline $\begin{array}{l}\text { Feed units kg-1 } \\
(1 \mathrm{fu}=9.3 \mathrm{MJ} \mathrm{NE})\end{array}$ & 1.00 & 1.01 & 1.03 & 1.01 & 1.02 & 1.00 & 0.99 & 0.99 \\
\hline Crude protein, $\mathrm{g} \mathrm{kg}^{-1}$ & 175 & 159 & 179 & 157 & 179 & 156 & 179 & 154 \\
\hline \multicolumn{9}{|l|}{$\begin{array}{l}\text { Apparent ileal digestible } \\
\text { amino acids, } \mathrm{g} \mathrm{fu}^{-1}\end{array}$} \\
\hline Lysine & 8.5 & 7.0 & 7.5 & 6.0 & 7.5 & 6.0 & 7.5 & 6.0 \\
\hline Methionine+cystine & 4.7 & 4.3 & 4.5 & 4.0 & 4.3 & 3.8 & 4.0 & 3.6 \\
\hline Threonine & 4.8 & 4.2 & 4.7 & 3.9 & 4.7 & 3.9 & 4.7 & 3.8 \\
\hline Calcium, $\mathrm{g} \mathrm{fu}^{-1}$ & 7.5 & 7.0 & 7.5 & 7.0 & 7.5 & 7.0 & 7.5 & 7.0 \\
\hline \multicolumn{9}{|l|}{ Phosphorus, $\mathrm{g} \mathrm{fu}^{-1}$} \\
\hline Digestible phosphorus, $\mathrm{g} \mathrm{fu}^{-1}$ & 2.7 & 2.5 & 2.7 & 2.5 & 2.7 & 2.5 & 2.7 & 2.5 \\
\hline $\begin{array}{l}\text { Organic feedstuffs, } \% \text { on dry } \\
\text { matter basis }^{b}\end{array}$ & 0 & 0 & 75 & 85 & 81 & 90 & 87 & 95 \\
\hline
\end{tabular}

aPer kilogram of feed, the premix contained Ca, $2.3 \mathrm{~g}$; P, $0.8 \mathrm{~g} ; \mathrm{Mg}, 0.5 \mathrm{~g}$; NaCl, $3.3 \mathrm{~g}, \mathrm{Fe}, 103 \mathrm{mg}$; Cu, $22 \mathrm{mg}$; Zn, 91 mg; Mn, 23 mg; Se, 0.28 mg; I, 0.28 mg; vitamin A, 5170 IU, vitamin $D_{3}, 517$ IU; vitamin E, 50 mg; thiamin, 2 mg; riboflavin, $5 \mathrm{mg}$; pyridoxine, $3 \mathrm{mg}$; vitamin $\mathrm{B}_{12} 20 \mu \mathrm{g}$; biotin, $0.2 \mathrm{mg}$; pantothenic acid, $14 \mathrm{mg}$; niacin, $20 \mathrm{mg}$; folic acid, $2 \mathrm{mg}$; and vitamin $\mathrm{K}, 2 \mathrm{mg}$.

${ }^{\mathrm{b}}$ Barley, peas, and lupins were organically produced.

weaning, eight piglets from each litter were randomly allotted to four pairs (one gilt and one barrow), and these were assigned to five dietary treatments according to an incomplete block design (Cochran and Cox 1957). From weaning to the age of 8 weeks, piglet pairs were housed as described for Experiment 1. Then they were moved to the fattening unit, where they were housed in $2.5-\mathrm{m}^{2}$ pens. Peat was used as bedding material.

The pigs in Treatment 1 were fed conventional weaner and fattening diets. The pigs in Treatments 2 to 5 received organic weaner and fattening diets that were based on organically grown barley, oats, dehulled oats (weaner diets only), and peas. The 
Partanen, K. et al. Feeding pigs with mainly home-grown organic feedstuffs

organic feedstuffs were from the same batches as in Experiment 1. In Treatment 2, organic feedstuffs were supplemented with warm-pressed rapeseed cake (CP $328 \mathrm{~g} \mathrm{~kg}^{-1}$ ) and fish meal (in weaner diet only, CP $705 \mathrm{~g} \mathrm{~kg}^{-1}$ ); in Treatment 3, with mechanically extracted whey protein concentrate (CP 695 $\mathrm{g} \mathrm{kg}^{-1}$ ); and in Treatment 4, with warm-pressed soya bean cake (CP $396 \mathrm{~g} \mathrm{~kg}^{-1}$ ) and whey protein concentrate (in weaner diet only). In Treatments $1-4$, the weaner diets were fed until piglets reached a body weight of $28 \mathrm{~kg}$, and they received the fattening diet until slaughter. In Treatment 5, the same organic diet was fed from weaning to slaughter, and it contained organically produced coldpressed rapeseed cake (CP $257 \mathrm{~g} \mathrm{~kg}^{-1}$ ) and whey protein concentrate as protein supplements. The formulations of the experimental diets are shown in Table 3. The conventional weaner and fattening diets were formulated to meet the nutrient requirements of weaned piglets and fattening pigs (Tuori et al. 1996), and they contained 9.5 and $8 \mathrm{~g}$ ileal digestible lysine $\mathrm{fu}^{-1}$, respectively. Lower apparent ileal digestible amino acid contents were accepted for organic diets. In Treatments 2-4, weaner and fattening diets contained 8 and $7 \mathrm{~g}$ ileal digestible lysine $\mathrm{fu}^{-1}$, respectively. In Treatment 5 , the diet that was fed from weaning to slaughter contained $7.5 \mathrm{~g}$ apparent ileal digestible lysine $\mathrm{fu}^{-1}$. Feeds were in meal form and they were prepared as in Experiment 1.

For 20 days after weaning, feeds were available ad libitum from gravity flow feeders. Thereafter, piglets were moved to the fattening unit, where they were fed according to the following restricted, age-based feeding scale: weaner diets from 1.0 to $1.6 \mathrm{fu} \mathrm{d}^{-1}$, and after reaching $28 \mathrm{~kg}$ of body weight, fattening diets from 1.7 to $3.3 \mathrm{fu} \mathrm{d}^{-1}$. Water was available ad libitum from drinking nipples. In the weaner unit, the piglets were weighed at birth, at weaning, and 13 and 20 days after weaning. In the fattening pig unit, the pigs were weighed weekly until they reached a weight of $28 \mathrm{~kg}$, then every second week for eight weeks, and finally weekly until they reached a body weight of $105 \mathrm{~kg}$ and were slaughtered. During the weaner phase, the incidence of post-weaning diarrhoea was scored daily as described in Experiment 1.

\section{Carcass and meat quality measurements}

In Experiments 2 and 3, carcass lean percentage was determined with a Hennessy grading probe GP4 (Hennessy Grading Systems Ltd., Auckland, New Zealand). The thickness of back fat was calculated as the mean of five measurements that were taken at the shoulder, in the middle, and at three locations of ham. The thickness of side fat was determined on the last rib, $8 \mathrm{~cm}$ from the midline. In Experiment 2, the firmness of back fat was scored using a scale of 9 to 15 , where higher values indicate firmer fat. Ham was dissected into fat and lean (including bones) to determine the lean percentage of ham. The colour of the longissimus dorsi muscle was determined with a Minolta DP301 device (Minolta Camera Co., Ltd., Osaka, Japan) in terms of lightness $\left(L^{*}\right)$, redness $\left(a^{*}\right)$, and yellowness $\left(b^{*}\right)$. Samples were taken from the longissimus dorsi muscle before the last rib from 37 and 60 randomly selected carcasses in Experiments 2 and 3 (one pig per pen), respectively, for the determination of organoleptic quality. The frozen samples were thawed and prepared for sensory evaluation as described by Siljander-Rasi et al. (1996). A trained, seven-member test panel graded the fried samples for tenderness, juiciness, and taste using a 7 -point rating scale $(1=$ very tough, very dry, weak pork flavour; 7 = very tender, very juicy, strong pork flavour). Each sample's mean score was calculated for use in the statistical analysis.

\section{Chemical analyses}

Feed ingredients were analysed for proximate composition before diet formulations. Samples were ground to pass through a $1-\mathrm{mm}$ sieve before analysis. Dry matter content was determined by drying at $103^{\circ} \mathrm{C}$ for $16 \mathrm{~h}$. The contents of ash, ether extract, and crude fibre were determined by standard methods (AOAC 1990). Nitrogen content (crude protein $=6.25 \times \mathrm{N}$ ) was determined by the Dumas method using a Leco FP 428 nitrogen analyser (Leco Corp., St Joseph, USA). The net energy content of the feedstuffs was calculated on the 


\section{AGRICULTURAL AND FOOD SCIENCE}

Vol. 15 (2006): 89-105.

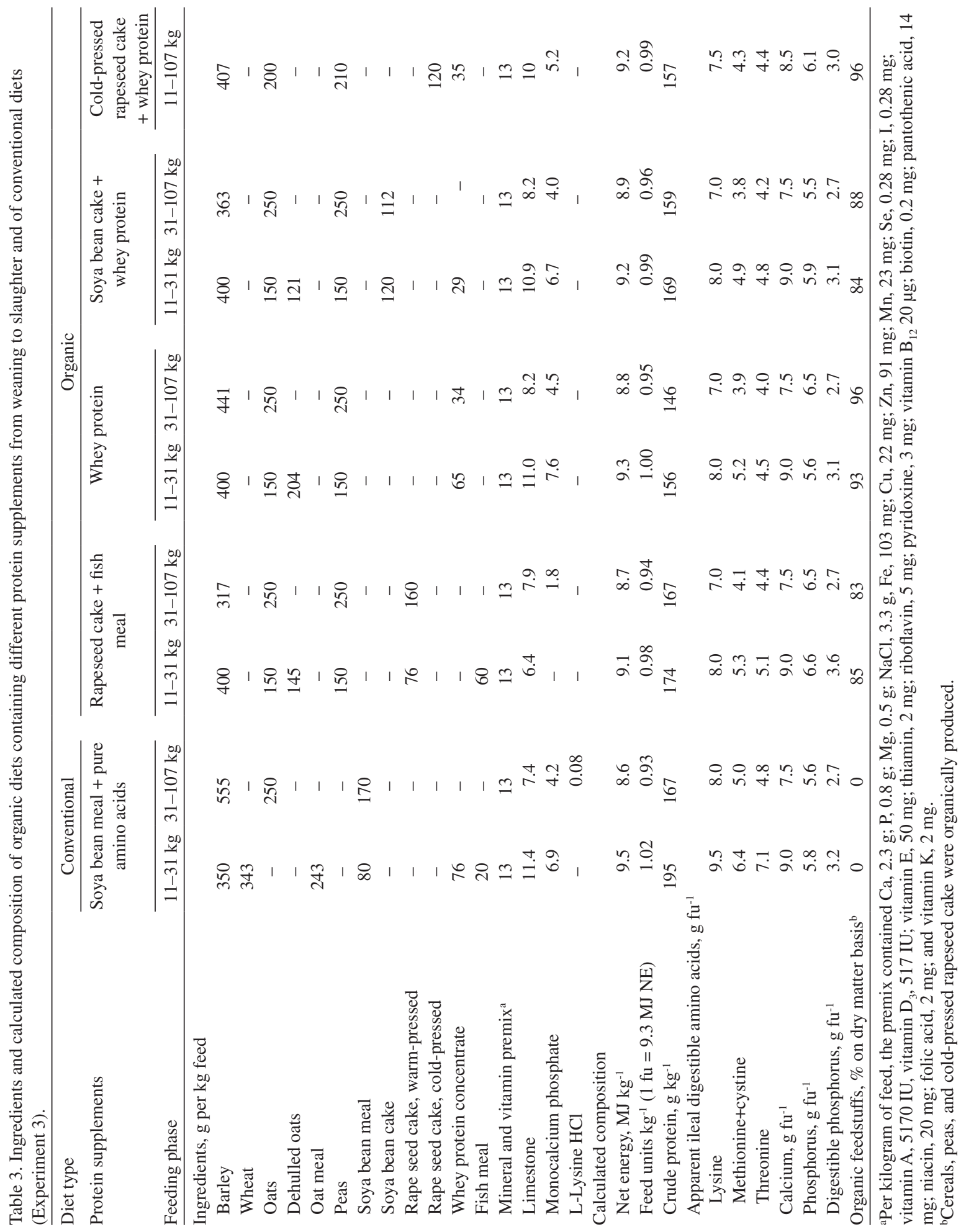


Partanen, K. et al. Feeding pigs with mainly home-grown organic feedstuffs

basis of proximate composition analysis and the tabulated digestibility coefficients as described by Tuori et al. (1996). The ileal digestible amino acid contents of the feedstuffs were calculated on the basis of tabulated (Tuori et al. 1996) or previously analysed amino acid composition (Partanen et al. 2003) and tabulated digestibility coefficients (Tuori et al. 1996).

\section{Statistical methods}

Statistical analyses were carried out using the MIXED procedure of SAS (The SAS® System for Windows, Release 8.02). The data of Experiments 1 and 3 were analysed using the following model (Cochran and Cox 1957): $\mathrm{Y}_{\mathrm{ijk}}=\mu+\mathrm{L}_{\mathrm{i}}+\mathrm{T}_{\mathrm{j}}+\mathrm{e}_{\mathrm{ij}}$, where $\mu$ is the overall mean, $L$ is the random effect of litter, $\mathrm{T}$ is the fixed effect of treatment, and e is the error distribution with a mean of 0 and the variance $\sigma^{2}$. In Experiment 1, differences between treatments were tested using the following orthogonal contrasts: 1) control diet vs. diets with peas or faba beans, 2) pea vs. faba bean diet, 3) 120 vs. $240 \mathrm{~g} \mathrm{~kg}^{-1}$ of peas or faba beans in the diet, and 4) interaction between dietary level and source of legume seed. Diets with legume seeds were also compared to the control diet using Dunnett's test. In Experiment 3, the differences between the treatments were tested using the Tukey test when the F-test was significant $(\mathrm{P}<0.05)$.

In Experiment 2, the data were analysed using the following model (Snedecor and Cochran 1989): $Y_{i j}=\mu+S_{i}+T_{j}+(S \times T)_{i j}+e_{i j}$, where $\mu$ is the overall mean, $\mathrm{S}, \mathrm{T}$, and $\mathrm{S} \times \mathrm{T}$ are the fixed effects of sex, treatment, and their interaction, respectively, and e is the error distribution with a mean of 0 and the variance $\sigma^{2}$. No significant interactions between sex and treatments were found, and therefore the data were pooled over sex in this paper. Differences between the treatments were tested using the following orthogonal contrasts: 1) conventional vs. organic diets, 2) linear effect of dietary lupin level, and 3) quadratic effect of dietary lupin level. In all experiments, residuals were checked for normality and plotted against fitted values.
The circulation rates of pigs in weaner and fattening units were calculated as follows: 365 / (length of growing period, $\mathrm{d}+2 \times$ standard deviation +10$)$. Feed costs were calculated based on the purchase price of commercial conventional and organic feedstuffs in Finland in 2001. Carcass prices were based on the conventional carcass prices of $€ 1.45$ and $1.48 \mathrm{~kg}^{-1}$ for $59 \%$ lean meat in carcasses of $<77 \mathrm{~kg}$ and $\geq 77 \mathrm{~kg}$, respectively, in 2001. Each percentage point increase or decrease in carcass lean percentage increased or decreased the carcass price by $€ 0.02 \mathrm{~kg}^{-1}$.

\section{Results and discussion}

\section{Peas and faba beans in diets for weaned piglets}

The proximate compositions of pea cv. Karita and faba bean cv. Kontu used in Experiment 1 were as follows: CP 187 and $280 \mathrm{~g} \mathrm{~kg}^{-1}$, ether extract 23 and $22 \mathrm{~g} \mathrm{~kg}^{-1}$, crude fibre 53 and $85 \mathrm{~g} \mathrm{~kg}^{-1}$, and ash 26 and $32 \mathrm{~g} \mathrm{~kg}^{-1}$, respectively. These values are in accordance with previous reports (Gatel 1994). According to Partanen et al. (2001), the protein of pea cv. Karita contained the following per $16 \mathrm{~g}$ of $\mathrm{N}$ : 7.0-7.1 g lysine, 0.7-0.9 g methionine, 1.5-1.7 $\mathrm{g}$ cystine, and 3.3-3.6 g threonine. The corresponding values for the protein of faba bean cv. Kontu were $5.9 \mathrm{~g}$ lysine, $0.5 \mathrm{~g}$ methionine, $1.3 \mathrm{~g}$ cystine, and $2.9 \mathrm{~g}$ threonine.

The performance results of weaned piglets offered diets containing 120 or $240 \mathrm{~g} \mathrm{~kg}^{-1}$ of peas or faba beans are summarised in Table 4 . The piglets offered the control diet achieved a weight gain of $328 \mathrm{~g} \mathrm{~d}^{-1}$. Those offered diets containing 120 or $240 \mathrm{~g} \mathrm{~kg}^{-1}$ of peas reached similar growth rates of 329 and $299 \mathrm{~g} \mathrm{~d}^{-1}$, respectively $(\mathrm{P}>0.05)$. The inclusion of 120 or $240 \mathrm{~g} \mathrm{~kg}^{-1}$ of faba beans in weaner diets tended to result $(\mathrm{P}=0.06)$ in slower growth rates (265 and $254 \mathrm{~g} \mathrm{~d}^{-1}$, respectively) than in pea diets. This difference in growth performance was seen more clearly during the first 13 days after 
Vol. 15 (2006): 89-105.

Table 4. Performance of weaned piglets fed organic diets with graded levels of peas and faba beans (Experiment 1).

\begin{tabular}{|c|c|c|c|c|c|c|c|c|c|c|}
\hline & \multirow[b]{2}{*}{ Control } & \multicolumn{2}{|c|}{ Peas, $\mathrm{g} \mathrm{kg}^{-1}$} & \multicolumn{2}{|c|}{$\begin{array}{l}\text { Faba beans, } \\
\qquad \mathrm{g} \mathrm{kg}^{-1}\end{array}$} & \multirow[b]{2}{*}{ SEM } & \multicolumn{4}{|c|}{ Contrasts $^{1}$} \\
\hline & & 120 & 240 & 120 & 240 & & 1 & 2 & 3 & 4 \\
\hline $\mathrm{N}$ & 8 & 8 & 8 & 8 & 8 & & & & & \\
\hline \multicolumn{11}{|l|}{ Weight, kg } \\
\hline At weaning & 11.8 & 11.9 & 11.9 & 11.5 & 11.7 & 0.63 & 0.93 & 0.45 & 0.82 & 0.85 \\
\hline $13 \mathrm{~d}$ after weaning & 14.9 & 15.2 & 14.8 & 13.8 & 14.2 & 1.03 & 0.56 & 0.11 & 0.97 & 0.46 \\
\hline $20 \mathrm{~d}$ after weaning & 18.2 & 18.3 & 17.7 & 16.7 & 16.6 & 1.30 & 0.32 & 0.08 & 0.65 & 0.75 \\
\hline \multicolumn{11}{|l|}{ Weight gain, $\mathrm{g} \mathrm{d}^{-1}$} \\
\hline $0-13 \mathrm{~d}$ after weaning & 242 & 261 & 224 & 179 & 198 & 48.2 & 0.37 & 0.05 & 0.75 & 0.29 \\
\hline 13-20 d after weaning & 501 & 471 & 450 & 437 & $367^{\mathrm{a}}$ & 63.3 & 0.16 & 0.19 & 0.30 & 0.57 \\
\hline 0-20 d after weaning & 328 & 329 & 299 & 265 & 254 & 47.1 & 0.20 & 0.06 & 0.47 & 0.74 \\
\hline \multicolumn{11}{|l|}{ Feed consumption, $\mathrm{kg} \mathrm{d}^{-1}$} \\
\hline $0-13 \mathrm{~d}$ after weaning & 0.64 & 0.75 & 0.65 & 0.61 & 0.60 & 0.071 & 0.75 & 0.04 & 0.20 & 0.33 \\
\hline 13-20 d after weaning & 1.07 & 1.13 & 1.06 & 1.03 & 0.97 & 0.109 & 0.77 & 0.20 & 0.36 & 0.95 \\
\hline $0-20 \mathrm{~d}$ after weaning & 0.78 & 0.87 & 0.78 & 0.75 & 0.72 & 0.078 & 0.96 & 0.07 & 0.22 & 0.57 \\
\hline Feed units per day & 0.81 & 0.89 & 0.78 & 0.76 & 0.70 & 0.078 & 0.62 & 0.04 & 0.11 & 0.62 \\
\hline $\mathrm{Kg}$ feed per $\mathrm{kg}$ gain & 2.14 & 2.80 & 2.53 & 2.63 & 3.11 & 0.487 & 0.21 & 0.65 & 0.81 & 0.41 \\
\hline Feed units per kg gain & 2.22 & 2.85 & 2.53 & 2.65 & 3.04 & 0.484 & 0.27 & 0.72 & 0.94 & 0.42 \\
\hline \multicolumn{11}{|c|}{ Incidence of post-weaning diarrhoea } \\
\hline Pens with no diarrhoea & 4 & 3 & 6 & 4 & 5 & & & & & \\
\hline Days of diarrhoea per pen & 2.3 & 5.6 & 2.3 & 2.4 & 2.1 & & & & & \\
\hline Diarrhoea index & 3.6 & 7.4 & 3.1 & 3.1 & 3.1 & & & & & \\
\hline Medicated piglets & 0 & 2 & 1 & 0 & 1 & & & & & \\
\hline
\end{tabular}

Contrasts: 1 = control diet vs. pea and faba bean diets, $2=$ pea vs. faba bean diets, $3=120 \mathrm{vs.} 240 \mathrm{~g} \mathrm{~kg}^{-1}$ peas or faba bean in the diet, $4=$ interaction $2 \times 3$.

a Significantly different from the control according to Dunnett's test $(\mathrm{P}<0.05)$.

weaning $(\mathrm{P}=0.05)$, when piglets offered faba bean diets consumed less feed than those offered pea diets $(P=0.04)$. Previous studies have shown that up to $150 \mathrm{~g} \mathrm{~kg}^{-1}$ of conventionally produced peas can be included in diets for piglets weighing 10-25 $\mathrm{kg}$, when no amino acid supplementation is used (Fékété et al. 1984).

The coefficient of variation in the weight gain of piglets (calculated from individual pigs) was generally high, $41 \%$ in the control treatment and $53-59 \%$ in the pea treatments and $57-60 \%$ in the faba bean treatments. Although the average weight gain of piglets fed legume seed diets was not dramatically decreased compared to that of the control group, the higher variation in the weight gain means that the pens of the weaner unit are occupied for a longer period than in the conventional production and that piglets have more heterogeneous body weights if they are moved at the same time to the fattening unit. The larger variation in weight gain of piglets fed pea and faba bean diets compared to those fed the control diet could be related to dietary amino acid imbalances or the effect of legumes on feed intake. Amino acid supplements are forbidden in organic production, and a balanced amino acid composition may be difficult to obtain when high levels of peas or faba beans are used in diets. In the present study, whey protein concentrate and fish meal were used as supplemental protein sources, and only diet that con- 
Partanen, K. et al. Feeding pigs with mainly home-grown organic feedstuffs

tained $240 \mathrm{~g} \mathrm{~kg}^{-1}$ faba beans did not fulfil the amino acid requirements of weaned piglets (Tuori et al. 1996). The inclusion of peas in weaner diets has been associated with reduced feed intake (Bengala Freire et al. 1991), but other studies have shown that even high levels of peas are palatable to piglets (Jondreville et al. 1992). Our results showed similar feed consumption in pea diets compared to that in the control, which is in accordance with previous studies (Grosjean et al. 1997, Van Cauwenberghe et al. 1997). However, we were not able to completely prevent or measure feed wastage on the floor, which was occasionally seen in pens. Although feed conversion ratios did not differ between the treatments $(\mathrm{P}>0.05)$, they were generally large, indicating that measured feed consumption included some feed wastage. If the palatability of legume diets is reduced, it could increase feed wastage.

Reduced feed consumption of piglets fed diets with $240 \mathrm{~g} \mathrm{~kg}^{-1}$ faba beans is in accordance with studies with growing pigs, where feed consumption was reduced at dietary faba bean levels above $200 \mathrm{~g} \mathrm{~kg}^{-1}$ (Aherne et al. 1977, Partanen et al. 2003). The differences in feed consumption between diets could be attributed partly to differences in energy content of diets and partly to a specific effect of legume seeds. Legumes were included in weaner diets at the expense of whey protein concentrate and dehulled oats, and the net energy content of diets declined with increasing legume seed inclusion. Piglets tend to increase feed intake to compensate lower dietary energy content, but at the highest faba bean level, they may not have been able to compensate sufficiently. The incidence of post-weaning diarrhoea was nearly equal among dietary treatments, and it does not explain the greater variation seen in the weight gain of piglets fed legume seed diets. The highest incidence of diarrhoea was observed in pigs offered diets containing $120 \mathrm{~g} \mathrm{~kg}^{-1}$ peas.

\section{Lupins in diets for growing-finishing pigs}

Lupins differ from other grain legumes in their chemical composition; the crude protein, ether ex- tract, and crude fibre contents are generally higher than in peas and faba beans (Gatel 1994). In Experiment 2, two batches of lupins grown organically in 1998 and 1999 were used in grower and finisher diets, respectively. The proximate compositions of these batches were as follows: CP 198 and $295 \mathrm{~g} \mathrm{~kg}^{-1}$, ether extract 73 and $66 \mathrm{~g} \mathrm{~kg}^{-1}$, crude fibre 186 and $155 \mathrm{~g} \mathrm{~kg}^{-1}$, and ash 41 and $34 \mathrm{~g} \mathrm{~kg}^{-1}$, respectively. The differences in proximate composition between these batches were probably caused by growing conditions; the growing season 1998 was rainy and cool compared to that of 1999. In addition, the yield was smaller in the former. Because the batch of 1998 was smaller and than that of 1999, the former one was used for grower diets. The amino acid compositions of the lupin batches of 1998 and 1999 were as follows (per $16 \mathrm{~g} \mathrm{~N}$ ): 4.8 and $3.9 \mathrm{~g}$ lysine, 0.7 and $0.5 \mathrm{~g}$ methionine, 1.7 and $1.5 \mathrm{~g}$ cystine and 2.9 and $3.2 \mathrm{~g}$ threonine, respectively. These are within the range of values reported previously (van Barneveld 1999). The carbohydrate composition of lupins is characterised by negligible levels of starch and high levels of soluble and non-soluble non-starch polysaccharides (Bach Knudsen 1997). When approximately half of the pea and faba bean dry matter is starch, the starch content of lupins is generally around $100 \mathrm{~g}$ $\mathrm{kg}^{-1}$ (van Barneveld 1999).

The performance results and carcass and meat quality of pigs fed the conventional diet and the organic diets with increasing lupin levels are presented in Table 5. Gradual replacement of rapeseed cake with lupins during the growing period exerted a quadratic effect on weight gain $(P=0.03)$, the highest growth rate being observed when $33 \%$ of rapeseed cake was replaced with lupins. Daily feed consumption tended to decrease quadratically $(\mathrm{P}=$ 0.07 ) in organic diets with increasing lupin levels. Daily feed consumption was $1.52,1.56$, and 1.46 fu in diets in which 0,22 , or $67 \%$ of rapeseed cake was replaced with lupins. In the finishing period, the pigs fed the conventional diet grew faster $(\mathrm{P}=$ 0.04 ) and tended to have a smaller feed conversion ratio $(\mathrm{P}=0.09)$ than those fed organic diets, whereas no differences were observed in daily feed consumption. The dietary lupin level did not have a significant effect on the performance of pigs fed 
Vol. 15 (2006): 89-105.

Table 5. Performance and carcass characteristics of fattening pigs fed organic diets in which rapeseed cake was gradually replaced with blue lupins or fed a conventional diet (Experiment 2).

\begin{tabular}{|c|c|c|c|c|c|c|c|c|}
\hline \multirow{2}{*}{$\begin{array}{l}\text { Diet type } \\
\text { Replacement level }\end{array}$} & \multirow[t]{2}{*}{ Conventional } & \multicolumn{3}{|c|}{$\begin{array}{l}\text { Organic, with gradual replacement } \\
\text { of rapeseed cake with lupins }\end{array}$} & \multirow[b]{2}{*}{ SEM } & \multirow{2}{*}{$\begin{array}{c}\text { Conven- } \\
\text { tional } \\
\text { vs. organic }\end{array}$} & \multicolumn{2}{|c|}{ Effect of lupin level } \\
\hline & & $0 \%$ & $33 \%$ & $67 \%$ & & & Linear & Quadratic \\
\hline $\mathrm{N}$ & 10 & 9 & 9 & 9 & & & & \\
\hline \multicolumn{9}{|l|}{ Weight, kg } \\
\hline Initial & 26.6 & 26.5 & 26.4 & 26.8 & 0.72 & 0.93 & 0.71 & 0.77 \\
\hline At 5 weeks & 50.1 & 49.2 & 50.1 & 48.9 & 0.89 & 0.46 & 0.83 & 0.33 \\
\hline Final & 105.3 & 105.0 & 104.6 & 105.3 & 0.52 & 0.52 & 0.71 & 0.45 \\
\hline Days in trial & 96.0 & 99.2 & 97.8 & 98.5 & 1.70 & 0.19 & 0.77 & 0.62 \\
\hline \multicolumn{9}{|l|}{ Weight gain, $\mathrm{g} \mathrm{d}^{-1}$} \\
\hline Growing & 711 & 686 & 718 & 668 & 14.9 & 0.23 & 0.38 & 0.03 \\
\hline Finishing & 883 & 849 & 844 & 865 & 12.7 & 0.04 & 0.35 & 0.43 \\
\hline Total fattening & 823 & 794 & 802 & 799 & 8.8 & 0.02 & 0.71 & 0.62 \\
\hline \multicolumn{9}{|l|}{ Feed consumption, $\mathrm{kg} \mathrm{pig}^{-1}$} \\
\hline Growing & 50.3 & 48.7 & 50.4 & 48.6 & 0.97 & 0.32 & 1.00 & 0.15 \\
\hline Finishing & 175.5 & 188.4 & 182.5 & 186.4 & 5.41 & 0.10 & 0.79 & 0.46 \\
\hline Total fattening & 225.8 & 237.1 & 232.9 & 235.0 & 5.70 & 0.15 & 0.80 & 0.67 \\
\hline \multicolumn{9}{|l|}{ Feed units per kg gain } \\
\hline Growing & 2.15 & 2.21 & 2.18 & 2.19 & 0.039 & 0.33 & 0.72 & 0.65 \\
\hline Finishing & 3.20 & 3.41 & 3.34 & 3.28 & 0.074 & 0.09 & 0.23 & 0.96 \\
\hline Total fattening & 2.87 & 3.04 & 2.99 & 2.99 & 0.053 & 0.02 & 0.56 & 0.64 \\
\hline Carcass weight, $\mathrm{kg}$ & 78.7 & 77.6 & 77.9 & 77.1 & 0.42 & 0.02 & 0.41 & 0.28 \\
\hline Slaughter loss, $\%$ & 25.5 & 26.1 & 25.5 & 26.6 & 0.35 & 0.17 & 0.28 & 0.07 \\
\hline Back fat, mm & 20.0 & 21.7 & 21.6 & 20.6 & 0.72 & 0.12 & 0.27 & 0.60 \\
\hline Side fat, $\mathrm{mm}$ & 14.4 & 15.5 & 14.5 & 13.6 & 0.83 & 0.89 & 0.11 & 1.00 \\
\hline Firmness of fat (score 9-15) & 12.8 & 12.6 & 12.3 & 11.9 & 0.23 & 0.03 & 0.04 & 0.71 \\
\hline Carcass lean, $\%$ & 59.0 & 58.4 & 58.4 & 58.0 & 0.41 & 0.11 & 0.48 & 0.70 \\
\hline Ham lean, \% & 86.8 & 85.7 & 85.7 & 86.8 & 0.38 & 0.07 & 0.05 & 0.30 \\
\hline \multicolumn{9}{|l|}{ Longissimus dorsi muscle } \\
\hline \multicolumn{9}{|l|}{ Colour } \\
\hline Minolta L* & 52.8 & 52.9 & 53.0 & 53.8 & 0.86 & 0.62 & 0.50 & 0.74 \\
\hline Minolta $a^{*}$ & 7.6 & 7.2 & 7.7 & 8.6 & 0.29 & 0.56 & 0.01 & 0.52 \\
\hline Minolta $b^{*}$ & 3.8 & 3.8 & 3.9 & 4.4 & 0.29 & 0.47 & 0.14 & 0.55 \\
\hline \multicolumn{9}{|l|}{ Eating quality (scores 1-7) } \\
\hline Tenderness & 4.9 & 4.8 & 5.0 & 4.7 & 0.06 & 0.73 & 0.20 & 0.01 \\
\hline Juiciness & 4.6 & 4.6 & 4.8 & 4.8 & 0.15 & 0.45 & 0.26 & 0.42 \\
\hline Taste & 4.5 & 4.6 & 4.8 & 4.6 & 0.19 & 0.46 & 0.99 & 0.43 \\
\hline Drip loss, $\%$ & 7.3 & 7.4 & 7.8 & 7.8 & 0.52 & 0.47 & 0.48 & 0.89 \\
\hline
\end{tabular}

organic diets. During the entire fattening period, pigs fed the conventional diet grew faster and utilised feed more efficiently than those fed organic diets, whereas the effect of dietary lupin level was not significant. According to van Barneveld (1999), blue lupins can be included in pig diets at high levels without having negative effects on feed intake or growth performance. The maximum recom- 
Partanen, K. et al. Feeding pigs with mainly home-grown organic feedstuffs

mended inclusion levels were $200-250 \mathrm{~g} \mathrm{~kg}^{-1}$ diet for growers and 300-350 $\mathrm{g} \mathrm{kg}^{-1}$ diet for finishers. The advantages of the conventional diet over organic diets in weight gain and feed conversion ratio were $25 \mathrm{~g} \mathrm{~d}^{-1}$ and $0.14 \mathrm{fu} \mathrm{kg}^{-1}$, respectively. The observed differences seen between conventional and organic feeding regimes are in accordance with the results of Sundrum et al. (2000). The impaired growth rate and feed conversion ratio of pigs fed organic diets can most likely be attributed to the lower dietary amino acid supply observed in organic diets compared to the conventional twophase feeding.

Lupins contain alkaloids, which have a bitter taste and can have negative effects on feed palatability. Alkaloid content in blue lupin seeds has ranged from 0.1 up to $2.6 \mathrm{~g} \mathrm{~kg}^{-1} \mathrm{DM}$ (Gdala et al. 1996, Christiansen et al. 1997, Wasilewko and Buraczewska 1999). Although alkaloids were not analysed in this study, they could be a possible reason for slightly decreased feed consumption in pigs fed high lupin diets. Alkaloid content of blue lupin seeds is influenced by growing conditions (Christiansen et al. 1997), and the feed intake of pigs decreases when the alkaloid content of the diet exceeds $0.2 \mathrm{~g} \mathrm{~kg}^{-1}$ feed (Godfrey et al. 1985). Lupin seeds also contain large amounts of $\alpha$-galactoside oligosaccharides, which cannot be hydrolysed in the small intestine due to the absence of the appropriate enzyme. These oligosaccharides are fermented by gastrointestinal bacteria, and large amounts of $\alpha$-galactosides in a diet can have an adverse effect on the digestibility of the diet (Salgado et al. 2002).

Carcass weight was slightly higher in the conventional than in the organic diets $(\mathrm{P}=0.02)$. The lower carcass weight and dressing percentage of animals receiving organic diets is probably due to a large gut fill caused by the higher fibre content of these diets. The differences in carcass lean percentage were not significant, although the highest values were observed for the conventional treatment. The lean percentage of ham increased linearly according to the dietary lupin level. Dietary treatments did not have significant effects on the thickness of back and side fat. The conventional diet resulted in firmer fat than the organic diets did
$(\mathrm{P}=0.03)$. Furthermore, the dietary lupin level decreased fat firmness linearly $(\mathrm{P}=0.04)$. The main fatty acids in lupin oil are linoleic $(48.3 \%)$, oleic (31.2\%), palmitic (7.6\%), and linolenic acid (5.4\%) (Hansen and Czochanska 1974). The large amounts of unsaturated fatty acids in lupin oil are probably responsible for the softer backfat observed in pigs fed lupin diets. Dietary treatments did not affect the meat colour, except that redness $\left(\mathrm{a}^{*}\right)$ increased linearly according to the dietary lupin level $(\mathrm{P}=$ 0.01 ). The dietary lupin level had a quadratic effect on meat tenderness, the highest values being observed in the treatment in which $33 \%$ of rapeseed cake was replaced with lupins. The juiciness and taste of the meat were not influenced by dietary treatments $(\mathrm{P}>0.05)$.

The coefficients of variation in weight gain and in the length of the fattening period were similar among the dietary treatments, ranging from 5.0 to $6.5 \%$ and from 6.5 to $8.3 \%$, respectively. Based on the average length of the experiment and its standard deviation, the number of fattening pig groups that could be raised per pig place per year was 3.0 in all the treatments. However, the feed costs of organic grower and finisher diets were $€ 0.02-0.04$ $\mathrm{kg}^{-1}$ higher than in the conventional diets. Total feed costs per pig were about $19 \%$ higher than in the conventional treatment. Furthermore, the carcass price remained $€ 0.01-0.03 \mathrm{~kg}^{-1}$ lower than in the conventional treatment, due to a slightly lower carcass lean percentage. Sundrum et al. (2000) reported that in organic production that was based on on-farm diets, feed costs per pig were $43-45 \%$ higher and the carcass price $2-7 \%$ lower than with conventional feeding.

\section{Comparison of organic feeding regimes from weaning to slaughter}

The performance results of weaned piglets and growing-finishing pigs fed the conventional or organic diets with different protein supplements are shown in Table 6. During the weaner phase, the piglets grew faster in the conventional than in the organic treatments $(\mathrm{P}<0.05)$, but differences be- 
Vol. 15 (2006): 89-105.

Table 6. Performance and carcass characteristics of pigs fed a conventional or organic diets with different protein supplements from weaning to slaughter (Experiment 3).

\begin{tabular}{|c|c|c|c|c|c|c|c|}
\hline \multirow{2}{*}{$\begin{array}{l}\text { Diet type } \\
\text { Protein supplements }\end{array}$} & \multirow{2}{*}{$\begin{array}{c}\text { Conventional } \\
\text { Soya bean meal } \\
+ \text { pure amino } \\
\text { acids }\end{array}$} & \multicolumn{4}{|c|}{ Organic } & \multirow[b]{2}{*}{ SEM } & \multirow[b]{2}{*}{$\mathrm{P}$} \\
\hline & & $\begin{array}{l}\text { Rapeseed cake } \\
\text { + fish meal }\end{array}$ & $\begin{array}{l}\text { Whey } \\
\text { protein }\end{array}$ & $\begin{array}{l}\text { Soya bean cake } \\
+ \text { whey protein }\end{array}$ & $\begin{array}{l}\text { Cold-pressed } \\
\text { rapeseed cake } \\
+ \text { whey protein }\end{array}$ & & \\
\hline $\mathrm{N}$ & 11 & 12 & 11 & 12 & 12 & & \\
\hline \multicolumn{8}{|l|}{ Weight, $\mathrm{kg}$} \\
\hline At weaning & 10.5 & 10.8 & 10.6 & 10.8 & 10.8 & 0.49 & 0.92 \\
\hline In the end of weaner phase & 31.1 & 30.1 & 30.7 & 31.3 & 30.5 & 0.50 & 0.36 \\
\hline Final & 107.6 & 105.7 & 106.9 & 105.4 & 107.1 & 0.95 & 0.38 \\
\hline \multicolumn{8}{|l|}{ Days in trial } \\
\hline Weaner phase & 43.6 & 45.2 & 45.8 & 47.4 & 47.7 & 2.07 & 0.15 \\
\hline Growing-finishing phase & 79.4 & 84.4 & 80.4 & 79.7 & 83.2 & 1.77 & 0.09 \\
\hline Total & $123.7^{\mathrm{a}}$ & $129.7^{\mathrm{bc}}$ & $126.0^{\mathrm{abc}}$ & $127.3^{\mathrm{abc}}$ & $130.9^{c}$ & 2.60 & 0.006 \\
\hline \multicolumn{8}{|l|}{ Weight gain, $\mathrm{g} \mathrm{d}^{-1}$} \\
\hline Weaner & $481^{\mathrm{b}}$ & $432^{\mathrm{a}}$ & $441^{\mathrm{a}}$ & $441^{\mathrm{a}}$ & $420^{\mathrm{a}}$ & 16.0 & 0.02 \\
\hline Growing-finishing & 967 & 906 & 959 & 939 & 929 & 19.8 & 0.08 \\
\hline Total & $793^{\mathrm{b}}$ & $739^{a}$ & $769^{\mathrm{ab}}$ & $751^{\mathrm{a}}$ & $740^{\mathrm{a}}$ & 15.1 & 0.01 \\
\hline \multicolumn{8}{|l|}{ Feed consumption, $\mathrm{kg} \mathrm{pig}^{-1}$} \\
\hline Weaner & 42.7 & 44.9 & 44.0 & 43.9 & 45.6 & 2.60 & 0.93 \\
\hline Growing-finishing & 216.1 & 228.3 & 217.4 & 215.0 & 217.0 & 4.34 & 0.14 \\
\hline Total & $258.7^{\mathrm{a}}$ & $273.0^{\mathrm{b}}$ & $261.7^{\mathrm{a}}$ & $259.3^{\mathrm{a}}$ & $262.6^{\mathrm{a}}$ & 3.90 & 0.03 \\
\hline \multicolumn{8}{|l|}{ Feed units per kg gain } \\
\hline Weaner & 2.17 & 2.36 & 2.23 & 2.11 & 2.29 & 0.144 & 0.49 \\
\hline Growing-finishing & $2.62^{\mathrm{a}}$ & $2.85^{\mathrm{c}}$ & $2.71^{\mathrm{ab}}$ & $2.79^{\mathrm{bc}}$ & $2.81^{\mathrm{bc}}$ & 0.056 & 0.02 \\
\hline Total & $2.52^{\mathrm{a}}$ & $2.71^{\mathrm{c}}$ & $2.61^{\mathrm{ab}}$ & $2.65^{\mathrm{bc}}$ & $2.70^{\mathrm{bc}}$ & 0.048 & 0.002 \\
\hline Carcass weight, $\mathrm{kg}$ & 79.8 & 79.1 & 79.4 & 78.6 & 80.6 & 0.75 & 0.33 \\
\hline Slaughter loss, $\%$ & 25.3 & 25.6 & 25.9 & 25.6 & 25.5 & 0.40 & 0.72 \\
\hline Back fat, mm & 21.3 & 21.0 & 21.6 & 21.8 & 22.8 & 0.68 & 0.19 \\
\hline Side fat, $\mathrm{mm}$ & 12.7 & 12.5 & 13.6 & 12.8 & 14.0 & 0.85 & 0.32 \\
\hline Carcass lean, $\%$ & $60.3^{b}$ & $59.0^{\mathrm{a}}$ & $59.1^{\mathrm{a}}$ & $58.8^{\mathrm{a}}$ & $59.1^{\mathrm{a}}$ & 0.32 & 0.002 \\
\hline Ham lean, \% & 87.7 & 87.9 & 87.0 & 87.6 & 87.1 & 0.41 & 0.09 \\
\hline \multicolumn{8}{|l|}{ Longissimus dorsi muscle } \\
\hline \multicolumn{8}{|l|}{ Colour } \\
\hline Minolta L* & 52.7 & 53.0 & 53.2 & 53.2 & 51.4 & 0.51 & 0.07 \\
\hline Minolta a* & $7.2^{\mathrm{a}}$ & $6.9^{\mathrm{a}}$ & $7.8^{\mathrm{b}}$ & $8.3^{\mathrm{b}}$ & $6.8^{\mathrm{a}}$ & 0.30 & 0.001 \\
\hline Minolta $b^{*}$ & $2.7^{\mathrm{b}}$ & $2.6^{\mathrm{ab}}$ & $2.9^{\mathrm{b}}$ & $3.5^{\mathrm{c}}$ & $2.1^{\mathrm{a}}$ & 0.20 & 0.001 \\
\hline \multicolumn{8}{|l|}{ Eating quality (scores 1-7) } \\
\hline Tenderness & 5.1 & 4.9 & 5.1 & 4.9 & 5.1 & 0.11 & 0.55 \\
\hline Juiciness & 5.0 & 5.1 & 5.1 & 5.1 & 5.0 & 0.18 & 0.99 \\
\hline Taste & 4.9 & 4.7 & 5.1 & 4.8 & 4.9 & 0.28 & 0.75 \\
\hline Drip loss, $\%$ & 7.7 & 7.0 & 8.2 & 7.8 & 5.9 & 1.12 & 0.21 \\
\hline
\end{tabular}

tween the organic treatments were not significant. Due to large variation, the differences in feed conversion ratio between the dietary treatments were not significant. The weaner phase up to $31 \mathrm{~kg}$ of body weight was $2-4$ days longer in the organic treatments than in the conventional treatment. The standard deviation of the length of the weaner period was slightly larger in the organic treatments 
Partanen, K. et al. Feeding pigs with mainly home-grown organic feedstuffs

than in the conventional treatment, and therefore the circulation rate of piglets per place in the weaner unit was lower (4.9-5.5 vs. 5.7 piglets grown per place per year).

The numbers of days that piglets had diarrhoea in the Treatments 1 to 5 were $4.2,3.5,3.7,4.2$, and 3.8 , respectively, and the diarrhoea index was 6.5 , $4.5,4.4,5.6$, and 5.2, respectively. Differences between the treatments were not significant. Four piglets each were medicated in both the conventional treatment and the organic treatment with rapeseed cake + fish meal, five were medicated in the organic treatment with soya bean meal + whey protein, and one in the organic treatment with coldpressed rapeseed cake + whey protein.

During the fattening period, no significant differences in weight gain were found between dietary treatments, although the highest growth rates were observed in the conventional treatment. The feed conversion ratio was also lowest in the conventional treatment, lower than in the organic treatments with rapeseed cake + fish meal, soya bean meal + whey protein, and cold-pressed rapeseed cake + whey protein $(\mathrm{P}<0.05)$. The highest feed conversion ratios were observed in diets that contained rapeseed cakes. The fattening period was 1-5 days longer in the organic treatments than in the conventional treatment. The total weight gain and the feed conversion ratio from weaning to slaughter was better in conventional than in organic diets $(\mathrm{P}<0.05)$, except for the organic diet that was supplemented with whey protein $(\mathrm{P}>0.05)$. The good performance of pigs fed the organic diet with whey protein can be attributed to the superior amino acid composition of whey protein compared to that of rapeseed and soya bean cakes. The advantage of conventional over organic diets from weaning to slaughter ranged from $24-54 \mathrm{~g} \mathrm{~d}^{-1}$ in weight gain and 0.09-0.19 fu kg-1 in feed conversion ratio. This is in accordance with Experiment 2 and previous studies. Sundrum et al. (2000) reported that organic diets containing faba beans and lupins resulted in reduced feed intake and reduced growth performance during the growing period but not in the finishing period. Pigs have been shown to perform equally well irrespective of the main dietary protein supplement, but lowering the die- tary lysine to energy ratio has reduced growth performance and carcass lean percentage (Szabó et al. 2001). The conventional treatment of this experiment is not representative of the most effective phase-feeding strategies where from four up to six feeds of different nutrient composition are used from weaning to slaughter. It is relevant to assume that differences in the growth performance of pigs between organic and conventional treatments would have been greater if the conventional treatment had consisted of more than two feeding phases.

Carcass lean percentage was about one percentage point lower in the organic treatments than in the conventional treatment. Sundrum et al. (2002) reported that the carcass lean percentage decreased from 56 to 53.6-55.6 when slaughter pigs were fed organic diets that contained faba beans, peas, and lupins as home-grown protein sources. The lightness $\left(\mathrm{L}^{*}\right)$ of meat was not influenced by dietary treatments, whereas some differences were observed in the redness $\left(\mathrm{a}^{*}\right)$ and yellowness $\left(b^{*}\right)$ of meat. No differences in the eating quality of pork were observed between dietary treatments $(\mathrm{P}>0.05)$. Although Sundrum et al. (2000) found increased intramuscular fat content in pigs fed organic diets, the results of Experiments 2 and 3 indicate that feeding organic diets to pigs does not result in noticeable changes in the eating quality of pork.

The coefficient of variation in the weight gain during the fattening phase was $8.8 \%$ in the conventional treatment and $9.0-12.4 \%$ in the organic treatments. The circulation rate of pigs in the fattening unit from 31 to $106 \mathrm{~kg}$ of body weight was 3.4 in the conventional treatment and 3.2-3.4 in organic treatments. Compared to Experiment 2 higher circulation rate of pigs fed the conventional diet could be explained by one-phase feeding from 31 to $107 \mathrm{~kg}$ of body weight. In multi-phase feeding of fattening pigs, higher apparent ileal digestible amino acid contents are generally used up a body weight of $55 \mathrm{~kg}$, and the limited amino acid supply may have reduced the growth rate of pigs during the first 4-5 weeks of the fattening phase. The costs for organic weaner diets were $€ 0.01-$ $0.05 \mathrm{~kg}^{-1}$ higher than for the conventional diet. The 
difference between fattening diets was $€ 0.05-0.06$ $\mathrm{kg}^{-1}$. Total feed costs per pig from weaning to slaughter were $26-44 \%$ higher in the organic treatments than in the conventional treatment. Because of lower carcass lean percentage, the carcass price was $€ 0.02-0.03 \mathrm{~kg}^{-1}$ lower in the organic treatments than in the conventional treatment. The reduced growth performance and carcass leanness and increased circulation rate and feed costs seen in pigs fed organic diets with a limited amount of conventional protein feedstuffs contribute to demands for higher consumer prices for organic pork than for conventionally produced pork. In this study, the proportion of conventional feedstuffs was still quite high, ranging from the allowed daily maximum of $25 \%$ to $4 \%$ of dry matter consumption. Therefore, the differences in performance and carcass quality of pigs fed organic and conventional diets can be expected to increase further when the use of $100 \%$ organic feedstuffs will be required.

\section{Conclusions}

In conclusion, peas can be used up to $240 \mathrm{~g} \mathrm{~kg}^{-1}$ of feed without negative effects on piglet performance or feed consumption, whereas it seems prudent to limit the dietary faba bean level to less than $120 \mathrm{~g} \mathrm{~kg}^{-1}$ feed. Blue lupins can be used at a level of $100-120 \mathrm{~g} \mathrm{~kg}^{-1}$ in diets for fattening pigs, but higher levels in the growing phase can reduce feed intake and growth performance slightly. Lupins also decrease the firmness of fat. Restrictions set in 2000 on the use of conventional feedstuffs in organic pig feeding make it difficult to formulate diets that meet the amino acid requirements of weaned piglets and fattening pigs. Therefore, lower dietary amino acid content needs to be accepted. In the present study, pigs that were fed organic diets based on home-grown feedstuffs with a limited amount of conventional protein feedstuffs from weaning to slaughter required up to one week longer to reach slaughter weight than pigs fed conventional diets. Because of lower dietary amino acid supply, carcass leanness was also reduced. The variation in the growth rate was larger in pigs fed organic diets than in those fed a conventional diet, particularly during the weaner period. Combined with the reduced growth rate, this contributed to a decreased circulation rate of pigs per weaner and fattener place per year. The cost of organic diets was $19-44 \%$ higher than that of conventional diets, and the decreased carcass leanness resulting from organic diets also lowered carcass prices.

Acknowledgements. The authors wish to thank the Finnish Ministry of Agriculture and Forestry for financing this study.

\section{References}

Aherne, F.X., Lewis, A.J. \& Hardin, R.T. 1977. An evaluation of faba beans (Vicia faba) as a protein supplement for swine. Canadian Journal of Animal Science 57: 321328.

AOAC 1990. Official methods of analysis. Association of Official Analytical Chemists, Inc., Arlington, VA. 1298 p.

Bach Knudsen, K.E. 1997. Carbohydrate and lignin contents of plant materials used in animal feeding. Animal Feed Science and Technology 67: 319-338.

Bengala Freire, J.B., Aumaitre, A. \& Peiniau, J. 1991. Effects of feeding raw and extruded peas on ileal digestibility, pancreatic enzymes and plasma glucose and insulin in early weaned pigs. Journal of Animal Physiology and Animal Nutrition 65: 154-164.

Christiansen, J.L., Jørnsgård, B., Buskov, S. \& Olsen, C.E. 1997. Effect of drought stress on content and composition of seed alkaloids in narrow-leafed lupin, Lupinus angustifolius L. European Journal of Agronomy 7: 307314.

Cochran, W.G. \& Cox, G.M. 1957. Experimental designs. New York: Wiley. 611 p.

EC 1999. Council Regulation (EC) No 18074/1999 of 19 July 1999 supplementing Regulation (EEC) No 2092/91 on organic production of agricultural products and indicators referring thereto on agricultural products and foodstuffs to include livestock production. Official Journal of European Commission L257: 1-28.

Fékété, J., Castaing, J., Lavorel, O., Leuillet, M. \& Quemere, P. 1984. Utilisation des pois protégineux par le porcelet sevré. Bilan des essais réalisés en France. Journées de la Recherche Porcine en France 13: 393-399.

Gatel, F. 1994. Protein quality of legume seeds for non-ruminant animals: a literature review. Animal Feed Science and Technology 45: 317-248. 


\section{AGRICULTURAL AND FOOD SCIENCE}

Partanen, K. et al. Feeding pigs with mainly home-grown organic feedstuffs

Gatel, F., Fekete, J. \& Grosjean, F. 1989. A note on the use of spring pea (Pisum sativum hortense) in diets for weaned pigs. Animal Production 49: 330-332.

Gdala, J., Jansman, A.J.M., van Leeuwen, P., Huisman, J. \& Verstegen, M.W.A. 1996. Lupins (L. luteus, L. albus, L. angustifolius) as a protein source for young pigs. Animal Feed Science and Technology 62: 239-249.

Godfrey, N.W., Mercy, A.R., Emms, Y. \& Payne, H.G. 1985. Tolerance of growing pigs to lupin alkaloids. Australian Journal of Experimental Agriculture 25: 791-795.

Grosjean, F., Jondreville, C., Bogaert, C., Bourdillon, A., Pyronnet, C., Le Guen, M.-P. \& Williatte, I. 1997. Utilisation d'aliments pour porcelets sevrés contenant $40 \%$ de pois. Journées de la Recherche Porcine en France 29: 197-204.

Hansen, R.P. \& Czochanska, Z. 1974. Composition of the lipids of lupin seed (Lupinus angustifolius L. var 'Uniwhite'). Journal of the Science of Food and Agriculture 25: 409-415.

Järvi, A., Kangas, A., Laine, A., Niskanen, M., Salo, Y., Vuorinen, M., Jauhiainen, L. \& Mäkelä, L. 2000. Results of official variety trials 1992-1999. Publications of Agricultural Research Centre of Finland. Series A 70. 216 p.

Jondreville, C., Grosjean, F., Buron, G., Peyronnet, C. \& Beneytout, J.L. 1992. Comparison of four pea varieties in pig feeding through digestibility and growth performance results. Journal of Animal Physiology and Animal Nutrition 68: 113-122.

Partanen, K., Alaviuhkola, T., Siljander-Rasi, H. \& Suomi, K. 2003. Faba beans in diets for growing-finishing pigs. Agricultural and Food Science in Finland 12: 35-47.

Partanen, K., Valaja, J., Jalava, T. \& Siljander-Rasi, H. 2001. Composition, ileal amino acid digestibility and nutritive value of organically grown legume seeds and conventional rapeseed cakes for pigs. Agricultural and Food Science in Finland 10: 309-322.

Salgado, P., Freire, J.P.B., Mourato, M., Cabral, F., Toullec, R. \& Lallès, J.P. 2002. Comparative effects of different legume protein sources in weaned piglets: nutrient di- gestibility, intestinal morphology and digestive enzymes. Livestock Production Science 74: 191-202.

Siljander-Rasi, H., Valaja, J., Alaviuhkola, T., Rantamäki, P. \& Tupasela, T. 1996. Replacing soya bean meal with heat-treated, low-glucosinolate rapeseed meal does not affect the performance of growing-finishing pigs. Animal Feed Science and Technology 60: 1-12.

Szabó, C., Jansman, A.J.M., Babinsky, L., Kanis, E. \& Verstegen, M.W.A. 2001. Effect of dietary protein source and lysine:DE ratio on growth performance, meat quality, and body composition of growing-finishing pigs. Journal of Animal Science 79: 2857-2865.

Sundrum, A. 2001. Organic livestock farming. A critical review. Livestock Production Science 67: 207-215.

Sundrum, A., Bütfering, L., Henning, M. \& Hoppenbrock, K.H. 2000. Effects of on-farm diets for organic pig production on performance and carcass quality. Journal of Animal Science 78: 1199-1205.

Tuori, M., Kaustell, K., Valaja, J., Aimonen, E., Saarisalo, E. \& Huhtanen, P. 1996. Rehutaulukot ja ruokintasuositukset. Helsinki: Yliopistopaino. 92 p.

van Barneveld, R.J. 1999. Understanding the nutritional chemistry of lupin (Lupinus spp.) seed to improve livestock production efficiency. Nutrition Research Reviews 12: 203-230.

Van Cauwenberghe, S., Jondreville, C., Beaux, M.F., Grosjean, F., Peyronnet, C., Williatte, I. \& Gatel, F. 1997. Performance de croissance du porcelet en post-sevrage obtenues avec des régimes à base de pois et manioc. Journées de la Recherche Porcine en France 29: 189196.

Wasilewko, J. \& Buraczewska, L. 1999. Chemical composition including content of amino acids, minerals and alkaloids in seeds of three lupin species cultivated in Poland. Journal of Animal and Feed Sciences 8: 1-12.

Woese, K., Lange, D., Boess, C. \& Bögl, K.W. 1997. A comparison of organically and conventionally grown foods - results of a review of the relevant literature. Journal of the Science of Food and Agriculture 74: 281-293. 


\title{
SELOSTUS
}

\section{Tilalla luonnonmukaisesti tuotettuihin rehuihin perustuva porsaiden ja lihasikojen ruokinta}

\author{
Kirsi Partanen, Hilkka Siljander-Rasi ja Timo Alaviuhkola \\ Maa- ja elintarviketalouden tutkimuskeskus
}

Vuonna 2000 voimaan tulleet EU:n luonnonmukaisen kotieläintuotannon säädökset muuttivat luonnonmukaisesti tuotettavien sikojen ruokintaa. Sikojen ruokinnan tuli perustua pääasiassa tilalla luonnonmukaisesti tuotettuihin rehuihin, tavanomaisesti tuotettujen rehujen käyttöä rajoitettiin ja puhtaiden aminohappojen käyttö kiellettiin. Uudet säädökset herättivät epäilyjä siitä, säilyvätkö luomusikojen hyvä kasvu ja ruhon laatu myös uusien säädösten mukaisilla ruokinnoilla. Kolmessa kokeessa selvitettiin luonnonmukaisen tuotannon säädösten mukaisten ruokintavaihtoehtojen vaikutuksia porsaiden ja lihasikojen tuotantotuloksiin sekä sianlihan syöntilaatuun.

Ensimmäisessä kokeessa tutkittiin herneen ja härkäpavun käyttömäärän $(0,120$ tai $240 \mathrm{~g} / \mathrm{kg}$ rehua) vaikutusta vieroitettujen porsaiden kasvuun ja rehun hyväksikäyttöön. Herneruokinnoilla olleet porsaat kasvoivat yhtä hyvin kuin kontrolliryhmän porsaat. Sen sijaan suurin härkäpapumäärä pienensi rehun kulutusta ja hidasti kasvua. Myös kasvun hajonta oli herne- ja papuruokinnoilla suurempi kuin kontrolliryhmässä.

Toisessa lihasikojen kasvatuskokeessa korvattiin luomuruokintojen rypsipuristeesta 0,33 tai $67 \%$ sinilupiinilla. Alkukasvatuksessa sikojen kasvu oli luomuruokinnoilla paras, kun kolmannes rypsistä oli korvattu lupiinilla, mutta suurempi määrä lupiinia hidasti kasvua. Loppukasvatuksen ja koko kokeen aikaiseen kasvuun lupiinin osuus ei vaikuttanut. Lupiinin osuuden suuretessa sikojen selkäsilava pehmeni.

Kolmannessa kasvatuskokeessa tutkittiin erilaisten valkuaistäydennysten vaikutusta sikojen kasvuun ja rehuhyötysuhteeseen sekä ruhon ja lihan laatuun luomuruokinnoilla vieroituksesta teurastukseen. Kaksivaiheisilla luomuruokinnoilla sikojen kasvu oli paras, kun kotoisia rehuja täydennettiin heravalkuaisella, seuraavaksi paras, kun valkuaistäydennyksenä olivat soijapuriste ja heravalkuaisjauhe, ja huonoin, kun valkuaistäydennyksenä olivat rypsipuriste ja kalajauho. Kylmäpuristettua rypsiä ja heravalkuaisjauhetta sisältäneellä yksivaiheruokinnalla olleiden sikojen kasvu ei eronnut muista kaksivaiheisista luomuruokinnoista.

Luomuruokinnoilla olleiden lihasikojen kasvatusaika oli kahdesta seitsemään päivään pidempi tavanomaiseen ruokintaan verrattuna. Luomuruokinnoilla olleiden sikojen ruhot olivat rasvaisempia kuin tavanomaisella ruokinnalla, mutta sianlihan syöntilaadussa ei ollut eroja. Luomuruokinnoilla rehukustannus ja sikojen kiertonopeus olivat suurempia ja ruhon arvo pienempi kuin tavanomaisella ruokinnalla. 